\title{
Women Writers and Literary-Religious Circles in the Elizabethan West Country: \\ Anne Dowriche, Anne Lock Prowse, Anne Lock \\ Moyle, Ursula Fulford, and Elizabeth Rous
}

\author{
M I C H E L IN E W H I T E \\ Carleton University
}

\section{REFLECTIONS ON METHOD: IDENTIFYING \\ LITERARY NETWORKS IN A LOCAL CONTEXT}

The reconstruction of literary circles, coteries, networks, and communities has long been a central scholarly practice in the study of Renaissance literature. As Claude Summers and Ted-Larry Pebworth note, the literary circle was one of the "essential material conditions for the production of literature in an era in which patronage relations were crucial and in which manuscripts were frequently circulated among coteries of sympathetic readers." ${ }^{1}$ However, critics have noted that literary circles are also constructed by scholars seeking to organize disparate materials in a coherent way. From this perspective, a literary circle might be described as a "cataloguing mechanism and as a heuristic, that is, a way to pose questions about textual production and reception"; as a "useful shorthand" to "explain a wide range of complex, often messy, social interactions"; or as a "kind of map on which to locate individual writers in relation to each other" and to a variety of issues and goals. ${ }^{2}$ Given the importance of the literary circle during

I would like to thank the Social Sciences and Humanities Research Council of Canada for funding this project through a Standard Research Grant. I would also like to thank Francis and Kishanda Fulford of Great Fulford House for allowing me to consult their family papers. I am grateful to Shane Hawkins for translating the Latin poems discussed in this article and to the anonymous reviewer at Modern Philology for providing very helpful suggestions.

1. Editors' introduction to Claude J. Summers and Ted-Larry Pebworth, eds., Literary Circles and Cultural Communities in Renaissance England (Columbia: University of Missouri Press, 2000), 1.

2. Judith Scherer Herz, "Of Circles, Friendship, and the Imperatives of Literary History," in Summers and Pebworth, Literary Circles, 15; Timothy Raylor, "Newcastle's

(C) 2005 by The University of Chicago. All rights reserved. 0026-8232/2005/10302-0003 $\$ 10.00$ 
the Renaissance and in contemporary criticism, it is notable that the reconstruction of such circles does not loom large in the study of Elizabethan and Jacobean women's writing. Although it is now recognized that women were members of literary and intellectual networks, their works are still usually examined as the productions of a single individual rather than as contributions to such networks, and when women writers are examined together it is usually because they produced works of the same genre or adopted similar strategies in representing their literary authority. ${ }^{3}$

There are, of course, many factors that account for this tendency. It is time-consuming and sometimes impossible to amass sufficient data to position women within literary and cultural communities. Little is known about the families and friends of many women writers, and their printed and manuscript works seldom provide clues about the intellectual circles in which these works were produced and read. There are also powerful institutional and disciplinary factors: Susan Frye and Karen Robertson note that the field of literary studies tends to privilege individual authors or genres rather than collective literary activities, and we must not underestimate the lasting influence of Virginia Woolf's conclusion that an aspiring Elizabethan poetess would have been so excluded from literary communities that she would have killed herself or "ended her days in some lonely cottage outside the

Ghosts: Robert Payne, Ben Jonson, and the 'Cavendish Circle,'” in Summers and Pebworth, Literary Circles, 92; editors' introduction to Summers and Pebworth, Literary Circles, 2.

3. Margaret Ezell argued long ago that women were active members of literary networks, particularly networks that exchanged works in manuscript. See her The Patriarch's Wife: Literary Evidence and the History of the Family (Chapel Hill: University of North Carolina Press, 1987). Victoria Burke also highlights women's engagement in literary networks in "Women and Early Seventeenth-Century Manuscript Culture: Four Miscellanies," Seventeenth Century 12 (1997): 135-50. With the exception of writers such as Mary Sidney Herbert and the Cooke sisters, Elizabethan women have not often been examined in terms of collective literary goals. Several recent studies, however, have begun to recover Anne Lock's place within literary circles: Louise Schleiner, Tudor and Stuart Women Writers (Bloomington: Indiana University Press, 1994); Susan Felch, " Noble Gentlewomen famous for their learning': The London Circle of Anne Vaughan Lock," ANQ 16 (2003): 14-19; Susanne Woods, "Anne Lock and Aemilia Lanyer: A Tradition of Protestant Women Speaking," in Form and Reform in Renaissance England: Essays in Honor of Barbara Kiefer Lewalski, ed. Amy Diane Boesky and Mary Thomas Crane (Newark: University of Delaware Press, 2000), 171-84; and Micheline White, "A Biographical Sketch of Dorcas Martin: Elizabethan Translator, Stationer, and Godly Matron," Sixteenth Centurv Journal 30 (1999): 775-92. 
village." ${ }^{4}$ Perhaps most important, though, is the fact that most scholarly resources are not especially conducive to reconstructing women's involvement in literary circles: Alfred Pollard and G. R. Redgrave's Short-Title Catalogue of Books (1475-1640), bibliographies of women writers, and electronic databases of printed and manuscript works such as Renaissance Women Online and the Perdita Project are organized alphabetically, chronologically, or by genre rather than by county, religious affiliation, or kinship. ${ }^{5}$ In sum, literary networks have not functioned as a key heuristic in the study of women's writing, and the impression often conveyed is that women read and wrote in relative isolation.

This article demonstrates that prioritizing geographical locality and seeking to excavate a region's literary, religious, and kinship networks can yield surprising results about women writers' engagement with local culture, their relationships to other female writers, and their representation by their male peers. The study begins with two writers from Devon and Cornwall: Anne Edgcumbe Dowriche, from Mount Edgcumbe (overlooking Plymouth harbor; see fig. 1) and then from Honiton (fifteen miles east of Exeter; see fig. 2), who is the author of The French Historie (1589), and Anne Vaughan Lock Dering Prowse, who moved around 1579 to Exeter, where she translated Of the Markes of the Children of God (1590). These two women are currently known to scholars of Elizabethan literature, but although they lived only

4. Editors' introduction to Susan Frye and Karen Robertson, eds., Maids and Mistresses, Cousins and Queens: Women's Alliances in Early Modern England (Oxford University Press, 1999), 6. Virginia Woolf, A Room of One's Own (New York: Harcourt, Brace, 1929), 53. Margaret Ezell discusses the influence of Woolf's problematic depiction of the isolated Elizabethan poetess in "The Myth of Judith Shakespeare: Creating the Canon of Women's Literature," New Literary History 21 (1990): 579-92.

5. Early English Books Online (http://eebo.chadwyck.com/home) and the CD-ROM version of Alfred Pollard and G. R. Redgrave's A Short-Title Catalogue of Books in England, Scotland, and Ireland and of English Books Printed Abroad, 1475-1640 (Charlottesville: Bibliographical Society of the University of Virginia, 1961) can search for texts from a geographical location, provided the location appears in the citation data. The Perdita Project database (http://human.ntu.ac.uk/perdita/index.html) is searchable by author, genre, first line of poetry, and repository. The texts in Renaissance Women Online (www.wwp.brown.edu/texts/rwoentry.html) are organized alphabetically, and the "topic essays" deal primarily with genres. There is an essay by Margaret Ezell on "coterie writing," but the database itself does not yet facilitate the uncovering of specific literary circles. For examples of annotated bibliographies, see Micheline White, "Recent Studies in Women Writers of Tudor England, 1485-1603 (mid-1993 to mid-1999)," English Literary Renaissance 30 (2000): 457-93; or Elaine V. Beilin, "Current Bibliography of English Women Writers, 1500-1640," in Renaissance Englishwomen in Print, ed. Anne Haselkorn and Betty Travitsky (Amherst: University of Massachusetts Press, 1990), 347-60. 


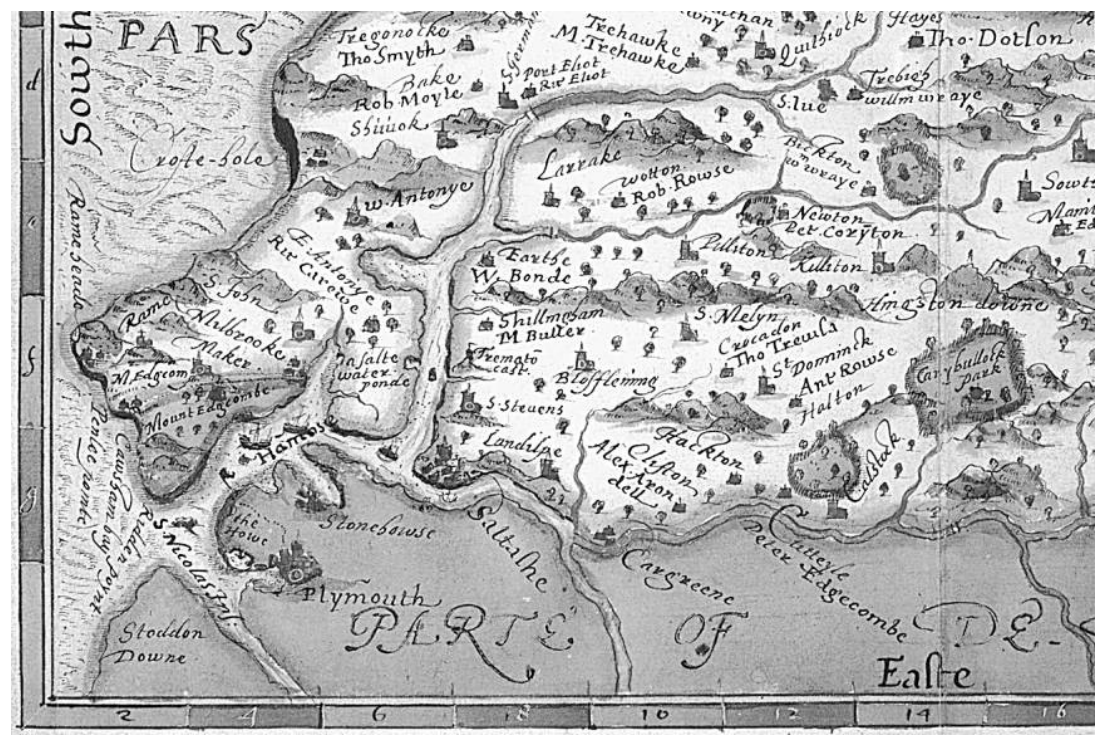

Figure 1. Detail from the map of East Hundred, Cornwall (ca. 1604), from John Norden's Speculum Britanniae. Trinity College Library, Cambridge, MS 0.4 .19 , fol. 179 r.

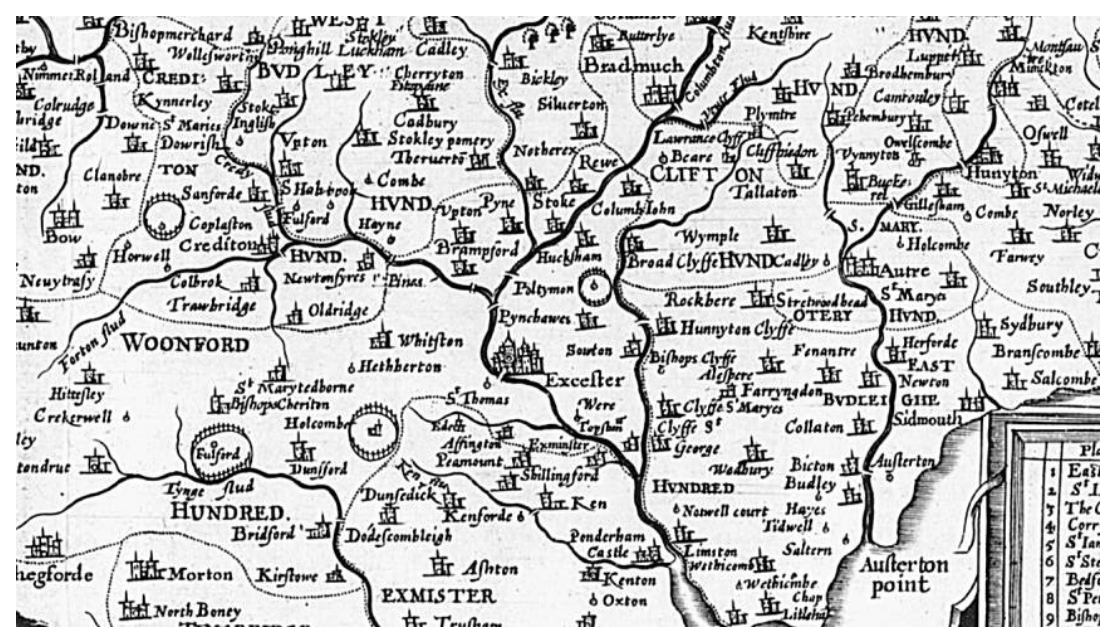

Figure 2. Detail from the map of Devon, from John Speed's The Theatre of the Empire of Great Britaine (London, 1611-12), fol. 19. STC (2nd ed.) 23041. Huntington Library. 
fifteen miles apart at the time their works were published, they have never been considered as members of a religious and literary community. ${ }^{6}$ By taking a closer look at the literary, religious, and political history of the West Country, I will demonstrate that Lock and Dowriche were related and part of a network of Puritan writers and that they had connections to previously unknown women who were also engaged in literary and religious activities but whose works are no longer extant. These women include Anne Lock's daughter, Anne Moyle, from Bake, Cornwall (west of Mount Edgcumbe; see fig. 1), who was praised for her facility with "Greek wit" and "Latin song"; Ursula Bampfield Fulford from Fulford House, Devon (eight miles west of Exeter; fig. 2), who was contrasted with Sappho and praised for her "prayers" and "songs"; and Elizabeth Southcote Rous from Halton, Cornwall (just north of Mount Edgcumbe; see fig. 1), who may have commissioned a reprinting of Katherine Parr's Prayers or Meditations. As we shall see, panegyric volumes, printed sermons, city documents, wills, and funeral monuments provide insight into these women's many contributions to shared ideological and literary goals and illuminate their connection to each other and to local ministers.

It should first be noted that these women were all from privileged social backgrounds; they were referred to as "gentlewomen" and were members of landed or merchant families that wielded political, economic, and religious power. The male members of these families filled local political offices and were responsible for defending the coast and maintaining social order. ${ }^{7}$ Like the landed gentry in many early modern counties, the families were interrelated, and some of their kinship ties were strong enough to be recorded in wills and printed works. In addition to being interrelated, some of the women of these families were neighbors and friends and would certainly have met each other. In The Survey of Cornwall (1602), Richard Carew from Antony House (between Mount Edgcumbe and Bake) reveals the importance of social intercourse to these particular families, praising the Rouses for their "kind \& uninterrupted entertainment" and noting

6. For a summary of recent criticism of Lock and Dowriche, see White, "Recent Studies," 473-75, 478.

7. Richard Prowse, Pearse Edgcumbe, Anthony Rous, and Amias Bampfield were Members of Parliament. For evidence of their interaction in Parliament, see P. W. Hasler, The History of Parliament: The House of Commons, 1558-1603, 3 vols. (London: His Majesty's Stationery Office [HMSO], 1981); and Sir Simon D'Ewes, The Journals of All the Parliaments during the Reign of Queen Elizabeth (London, 1682). Robert Moyle, Anthony Rous, and Pearse Edgcumbe were justices of the peace (JP). Thomas Fulford was a JP and a captain of the musters; Richard Prowse was involved in Exeter's defense; and Pearse Edgcumbe was deputy-lieutenant of Cornwall. 
that the local gentry "converse familiarly together, \& often visit one another. A Gentleman and his wife will ride to make mery with his next neighbour; and after a day or twayne, these two couples goe to a third: in which progresse they encrease like snowballs, till through their burdensome waight they breake againe." ${ }^{8}$ As we shall see below, it is possible that the women also met at sermons or religious exercises in Exeter or Saltash or in private homes.

In addition to "visiting" and "conversing together," these families contributed to shared religious and aesthetic goals; evidence, though fragmentary, enables us to place these women within overlapping religious and literary circles. The women were all zealous Protestants who used their literary gifts, wealth, and power to promote "godliness," to combat religious apathy, and to eradicate Catholicism. Anne Lock, Anne Dowriche, Anne Moyle, and Elizabeth Rous can all be linked to a network of radical preachers and patrons, and all contributed to international "godly" causes. In addition, the families valued education and literature, and the women wrote (or are praised in) texts that promote shared aesthetic and cultural ideals. Dowriche and Fulford are identified with the project of combating "wanton" poetry with religious verse; Lock, Fulford, and Dowriche supported the use of the printing press to educate the less learned. Lock and Dowriche wrote short ballad-meter poems to console the afflicted, and textual evidence suggests that they may have influenced each other. It is possible, moreover, to prove that manuscripts and printed works circulated between some of these families. Charles FitzGeffrey's Affaniae: Sive Epigrammatum Libri Tres (1601) and Richard Carew's The Survey of Cornwall reveal that texts circulated between the Rouses, the Moyles, and the Carews and that Anne Lock and Anne Moyle were admired by this community for their learning.

As several recent studies have argued, there was no fixed concept of the female writer at this time: not only were the terms "writer" and "author" in a state of flux owing to technological, religious, and social changes, but men employed different concepts of the female writer to serve a variety of professional and personal agendas. ${ }^{9}$ The evidence offered here supports such a view: in this West Country community,

8. Richard Carew, The Survey of Cornwall (London, 1602), 113v, 64v.

9. Jennifer Summit, Lost Property: The Woman Writer and English Literary History, 1380-1589 (University of Chicago Press, 2000); Wendy Wall, The Imprint of Gender: Authorship and Publication in the English Renaissance (Ithaca, NY: Cornell University Press, 1993); and Margaret W. Ferguson, "Renaissance Concepts of the 'Woman Writer," in Women and Literature in Britain, 1500-1700, ed. Helen Wilcox (Cambridge University Press, 1996), 143-68. 
the spouses, relatives, friends, and dependents of female writers drew on a wide range of conceits as they balanced traditional gender norms with the desire to publicize the women's noteworthy accomplishments. Thus we find representations ranging from fulsome praise to implicit support to curious silence, and, although the sample size is small, it is worth noting that the dependent preachers are the most explicitly enthusiastic about the women's achievements. ${ }^{10}$

\section{ANNE EDGCUMBE DOWRICHE AND HUGH DOWRICHE}

The first woman to be considered is Anne Edgcumbe Dowriche (born before 1560; married 1580), a member of the landed Edgcumbe family and the wife of Hugh Dowriche, the rector of Honiton, a town fifteen miles east of Exeter. ${ }^{11}$ Anne Edgcumbe Dowriche's The French Historie draws attention to its West Country origins: the Edgcumbe family arms are printed on the recto of the title page; the prefatory epistle is signed from "Honiton in Devon"; and the book is dedicated to Anne's brother "Master Pearse Edgecombe, of Mount Edgecombe in Devon, Esquier." 12 Carew's The Survey of Cornwall suggests that Mount Edgcumbe was a source of pride for the local gentry: it is the only house in the book to receive a detailed description, and Carew boasts that he "would presume to ranke it, for health, pleasure, and commodities, with any subjects house of his [Pearse Edgcumbe's] degree in England." 13 Anne's poem was printed with two imprints: one was sold in London while the other was sold by "William Russell, dwelling at Exeter," an imprint that was no doubt read by members of the Edgcumbe family, by the landed families near Mount Edgcumbe, and by like-minded readers from Exeter and other parts of the West Country.

10. This evidence modifies Summit's demonstration that certain male writers represented women writers as "lost" in order to define themselves as part of a vernacular literary tradition (Lost Property). It also differs from Mary Ellen Lamb's observation that Mary Sidney was recognized as a writer only by an established poet while her authorship was denied, distorted, or sexualized by writers who were dependent on her patronage (Mary Ellen Lamb, Gender and Authorship in the Sidney Circle [Madison: University of Wisconsin Press, 1990], 28-71).

11. For fuller biographical details, see Elaine V. Beilin, "Anne Dowriche," in Dictionary of Literary Biography, 4th ser., 172 (1996): 79-84.

12. Anne Dowriche, The French Historie. That is; A Lamentable Discourse of Three of the Chiefe, and Most Famous Bloodie Broiles that have Happened in France for the Gospell of Jesus Christ (London, 1589), A4v, A2r, A2v. All subsequent parenthetical citations for The French Historie are from this text.

13. Carew, Survey, 99v. 
A second short poem by Anne, "Verses written by a Gentlewoman, upon the Jaylors Conversion," appeared in the prefatory material of her husband's The Jaylors Conversion (1596), a sermon based on the conversion of the jailer of Paul and Silas (Acts 16:30). Hugh states that his text is based on a sermon delivered in 1580 and that the sermon was relevant again during a time of spiritual backsliding and possible foreign invasion. ${ }^{14}$

Although very little is known about the personal lives of Anne and Hugh, both volumes contain the kind of religious rhetoric associated with the more "godly" or "Puritan" wing of the church: they insist on the need for complete submission to the authority of the Word; they are preoccupied with resistance, imprisonment, and suffering for the "truth"; they inveigh against the spiritual apathy of the average Englishman; and they are vehemently anti-Catholic. As we shall see, not only would the religious content of the two volumes have appealed to the other local families, but compelling connections exist between the Dowriches' works and the political activities of their dedicatees and of the other neighboring gentry families. ${ }^{15}$

The activities of the Dowriches' dedicatees warrant careful attention. For example, The Jaylors Conversion is dedicated to Valentine Knightley, a man Hugh describes as his "first friend" (5r), and although Knightley was from Northamptonshire, he was known in Devon because he represented Tavistock in Parliament owing to the influence of the earl of Bedford and the earl of Warwick. ${ }^{16}$ More importantly, Valentine Knightley and his father, Sir Richard, supported two Puritan ministers who were active in Devon, Eusebius Paget and Edmund Snape, and all four men were penalized for their nonconformity. In 1576, while Hugh Dowriche was at Oxford with Valentine, Sir Richard Knightley was chastised by the queen for supporting a Puritan "exercise" moderated by Eusebius Paget. Paget then moved to the West Country, but he was deprived of his ministry in 1584 for arguing that his

14. Hugh Dowriche, The Jaylors Conversion (London, 1596), A6v-A7r. All subsequent parenthetical citations for The Jaylors Conversion are from this text.

15. The most authoritative account of Elizabethan Puritanism is Patrick Collinson, The Elizabethan Puritan Movement (1967; reprint, Berkeley: University of California Press, 1990). Ian W. Gowers, Puritanism in the County of Devon between 1570-1641 (PhD diss., University of Exeter, 1970), provides an analysis of the movement in Devon. This article draws extensively on Gowers.

16. Hasler, History, 2:405-7. Beilin also discusses the connection between Knightley and Hugh Dowriche in "'Some freely spake their mind': Resistance in Anne Dowriche's French Historie," in Women, Writing and the Reproduction of Culture in Tudor and Stuart Britain, ed. Mary E. Burke et al. (Syracuse University Press, 2000), 124. 
"conscience" prevented him from conforming to parts of the prayer book. ${ }^{17}$ In 1589, Sir Richard Knightley was imprisoned for harboring the illegal Marprelate Press, and Valentine Knightley worked on behalf of imprisoned preachers, visiting Edmund Snape in prison and smuggling out an account of his trial. ${ }^{18}$ Snape, who had previously preached near Exeter, rejected parts of the prayer book that did not conform to the "Word of God," compared the bishops to Catholic persecutors, and prayed that God would "strengthen our faith, and arm us with patience." ${ }^{19}$ In 1605 , Valentine and his father signed a petition in support of suspended Puritan ministers, and for this they were called before the Privy Council, temporarily stripped of their political offices, and accused of displaying "litle lesse then treason" and "sedition" in opposing the king in matters of religious policy. ${ }^{20}$

As we have seen, The French Historie's prefatory materials foreground the status and power of the Edgcumbe family, and like the Knightleys, some of the Edgcumbes supported local nonconformist activities. For example, Anne's brother, Richard, and one of Pearse's children, Catherine, patronized Puritan ministers such as Melanchthon Jewell. ${ }^{21}$ Jewell was notorious: he was imprisoned in Exeter in 1585 for refusing to conform to the prayer book; he was imprisoned in London (with Snape) in 1590 and accused of claiming that "justices had become tyrants"; and he preached illegally in private houses in the West Country until $1604 .^{22}$ In 1604 , he was apprehended with incriminating papers, including a list of "resolute Puritans" from Devon and Cornwall who sought legal advice on resisting ecclesiastical canons. ${ }^{23}$ One of the "resolute Puritans" on Jewell's list, Robert Campion, had been admitted to the parish of Rame in 1586 by Anne's brother, Richard Edgcumbe from Cotehele (next to Halton), and Anne's

17. Collinson, Elizabethan, 193. Benjamin Brook, The Lives of the Puritans, 3 vols. (London, 1813), 2:255.

18. Richard Bancroft, Dangerous Positions and Proceedings (1593; reprint, Farnborough, Hants.: Gregg International, 1968), 92. The first Marprelate pamphlet demands that Paget be restored to his West Country living (Martin Marprelate [pseud.], The Epistle [1588], 28).

19. Brook, Lives, 1:412, 413.

20. Hasler, History, 2:405-7; John Chamberlain, Letters, ed. Elizabeth McClure Thomson (New York: Putnam, 1965), 1:203.

21. In her 1589 dedication, Anne Dowriche sends a greeting to Pearse's wife and grown "children" (A2v). Catherine was one of these children.

22. Brook, Lives, 1:408-9. Gowers, Puritanism, 36-37, 51-54.

23. Gowers prints a transcription of these papers and discusses the names on the list in Puritanism, 54-88 and 281-89. 
niece, Catherine Edgcumbe, married Sir Edmund Prideaux, a lawyer who met with Jewell to provide the Puritans with legal advice. ${ }^{24}$ More strikingly, just before Jewell's arrest, Catherine and Edmund Prideaux welcomed him into their home at Farway (four miles south of Honiton), where he preached illegally on Revelation 2:2, a verse that recalls the conviction of the Dowriches and Snape that the godly needed strength and patience to survive in a hostile world. ${ }^{25}$

The works by Anne and Hugh share the religious vocabulary articulated by these nonconformists and contain episodes that closely resemble their experiences. In The French Historie, a poetic account of three incidents from the French religious wars, Anne celebrates the Huguenots who are imprisoned for participating in a godly "exercise" in a private home $(4 \mathrm{v})$ and the friends who work to secure their release (6r). She also depicts a senator whose "conscience" leads him to reject the king's demand for religious conformity (9r-16v); a nobleman who provides a lengthy defense of political resistance (29r-v); a group of godly citizens imprisoned in the "Clinke" (32r); and a preacher from the provinces who refuses to abandon scriptural truth $(34 \mathrm{r}-35 \mathrm{v}) .{ }^{26}$ The Jaylors Conversion addresses similar themes, and in applying Acts 16:30 to England, Hugh and Anne castigate magistrates who misrepresent

24. Gowers, Puritanism, 66-67. The Edgcumbes apparently promoted other "godly" preachers. In a Puritan survey from 1586, the vicar of the Edgcumbes' parish of Maker was described as a "godly preacher" who "feareth the lord unfainedlye," and the incumbent of Rame (before Campion) was also listed as a godly preacher. Albert Peel, ed., The Seconde Parte of a Register (Cambridge University Press, 1915), 1:110.

25. Gowers, Puritanism, 287-89. Catherine and Edmund Prideaux were married by about 1595. Farway was only four miles from Honiton, and it is possible that the Dowriches attended Jewell's sermon if they were still alive. We might recall that Anne Dowriche notes that "women of great parentage" were among the Huguenots participating in illegal exercises in a private home (5r). Edmund's mother, Phillipa Prideaux (died 1597), was also a Puritan who supported Eusebius Paget and was praised in language that suggests that she identified with the kind of suffering celebrated by Anne Dowriche. Phillipa Prideaux was praised for loving "the glorious gospell of Jesus Christ" despite being "disdayned, skoft and scorned at" (Ludwig Lavater's The Book of Ruth Expounded in Twenty-eight Sermons, trans. Ephraim Paget [London, 1586], 2v-3r).

26. Anne Dowriche encourages her readers to apply the French incidents to contemporary England, and, as Elaine Beilin demonstrates, there are clear verbal echoes between the defiant speeches made by the Huguenot senator Annas Bugaeus and those made by Puritan parliamentarians who resisted the queen's attempt to restrict discussion of religious conformity (Beilin, "Some Freely," 119-40). Dowriche's reference to the "Clinke" is particularly suggestive: two of the Marprelate pamphlets mention the imprisonment of Puritans in the Clink: The Epistle (1588), 49; and Hay Any Work for Cooper (1589), 2r. Richard Bancroft complained that the Puritans mischaracterized the government's treatment of them and that the "Clinke" and other prisons were "their onlie arguments" (Bancroft, Dangerous, 57). 
the truth as "sedition \& conspiracy" and "vex the poore elect" ( $7 \mathrm{r}$ and Anne's "Verses," 30); they celebrate those who suffer for the truth (8v$9 \mathrm{v}$ and "Verses"); and they exhort readers to imitate the converted jailer's submission to the Word (20v-22v and "Verses," 41-44).

\section{ANNE LOGK AND ANNE DOWRICHE}

Anne Dowriche was not the only learned and Puritan woman writer in Devon: her kinswoman Anne Vaughan Lock Dering Prowse was also a learned writer with ties to Puritan circles. A close friend of John Knox, Anne Lock had been a Marian exile and a member of the London Puritan community in the 1560 s and 1570 s. ${ }^{27}$ On December 7, 1579, she married her third husband, "Richard Prowze, gent," a wealthy draper from Exeter who filled several political offices, including the mayoralty. ${ }^{28}$ Dowriche and Lock were related through the Prowses, for Richard Prowse's daughter, Winifred, married Hugh Dowriche's cousin, Thomas Dowriche, and Prowse bequeathed money and goods to this daughter in his will. ${ }^{29}$ The women were also related through the Carew family of Antony House: Richard Carew was Anne Dowriche's nephew, and he was related to the Locks through his wife, Juliana Arundell. ${ }^{30}$ It is almost certain that the women would have

27. In what follows I offer new evidence pertaining to Lock's life in Exeter. The earlier parts of Lock's life are described in Patrick Collinson, "The Role of Women in the English Reformation Illustrated by the Life and Friendships of Anne Locke," (1965), in his Godly People: Essays on English Protestantism and Puritanism (London: Hambledon Press, 1983), 273-87; and in The Collected Works of Anne Vaughan Lock, ed. Susan M. Felch (Tempe: Arizona Center for Medieval and Renaissance Studies, 1999).

28. Joseph Lemuel Chester, ed., Parish Registers of St. Thomas the Apostle, London, 1558-1754 (London, 1881), 6. Prowse was sheriff of Exeter in 1576, alderman in 1579, mayor in 1578 and 1589, and Member of Parliament in 1584-85. Anne's responsibilities as the wife of the mayor can be glimpsed in the Exeter Act Book; in April 1589, the earls of Huntington and Essex and Sir Francis Knolles visited Exeter, and it was "ordered that the dyet of the said Erles shalbe at Mr. Mayor's house." James Hamilton Wylie, comp., Report on the Records of the City of Exeter (London: HMSO, 1916), 317.

29. Prerogatory Court of Canterbury Wills, 83 Huddleston. J. L. Vivian, ed., The Visitations of the County of Devon, Comprising the Herald's Visitations of 1531, 1564, and 1620. With Additions (Exeter, 1895), 290, 628.

30. These relationships are described in Carew's Survey: Carew praises Anne Dowriche's father and notes that he himself was a member of the Edgcumbe House, 99v100r. Juliana's mother was a Cosworth, and Carew explains that Coswarth House in Cornwall passed from Juliana's grandfather to the heirs of Dorothy Lock and John Cosworth of London, thereby revealing that the Carew-Cosworth-Lock connection was important even if distant, 144-45. For genealogical charts, see Richard Carew of Antony: The Survey of Cornwall, ed. F. E. Halliday (London: Andrew Melrose, 1953), 311-12. 
been aware of each other's literary works, and, as we shall see, they may even have directly influenced each other.

In 1590, Anne Lock published a translation of Of the Markes of the Children of God, a prose treatise by the Belgian-born Protestant minister Jean Taffin that addresses the suffering experienced by the Protestants in the Low Countries. The volume concludes with a short original poem, and it is dedicated to the countess of Warwick, whose husband, the earl of Warwick, had assisted Valentine Knightley, Hugh Dowriche's "first friend," to a parliamentary seat. The book was evidently widely read; there are extant editions from 1591, 1597, 1599, 1608, 1615, and 1634. Lock's dedication and poem draw specifically on Taffin's discussion of persecution, imprisonment, and martyrdom, and in the context of Lock's and Warwick's documented support of Puritanism, this strongly suggests that the work was printed to encourage the Puritan community during a time of crisis. ${ }^{31}$ Although Dowriche and Lock published works with different generic characteristics, the women shared the same religious outlook, and their works would have appealed to readers with similar religious sensibilities; both women understand the true church to be "under the cross," and they encourage the godly to remain committed to the truth in spite of imminent afflictions. For instance, in applying Taffin's treatise to the English context, Lock claims that although "the glorious Gospell” has enjoyed success in England, it is "now time" for everyone who is a "true professor" to prepare for "the day of trial." 32 Asserting that afflictions are the inevitable lot of the "children of God," she chastises the naive, the lazy, and the weak; she exhorts them to join the godly by imitating their "neighbours" (76) and running on their course "with cherefulnes and hope, having Christ so mightie a King, for our Captaine \& guide, who ... for the glorie that was set before him, indured the crosse" (77). Similarly, Dowriche explains that she has versified the account of the French martyrs in order to "edifie, comfort, and stirre up the godlie mindes unto care, watchfulnesse, zeale, \& ferventnesse in the cause of Gods truth"; and she claims that there is no text "which is more forceable to procure comfort to the afflicted ... and patience unto them that are persecuted" (A3v-A4r). The Huguenots in Dowriche's

31. For a detailed discussion of this argument, see Micheline White, "Renaissance Englishwomen and Religious Translations: The Case of Anne Lock's Of the Markes of the Children of God (1590)," English Literary Renaissance 29 (1999): 375-400.

32. Anne Lock's translation of Jean Taffin's Of the Markes of the Children of God, in Lock, Collected Works, 76. All subsequent parenthetical citations of this text are from this source. 
poem $(6 \mathrm{r}, 7 \mathrm{v}, 33 \mathrm{r})$ offer the same arguments about the causes and joys of suffering as those found in Lock's short poem, and both The French Historie and Of the Markes point to passages such as 2 Timothy 3:13, Philippians 1:28-29, Romans 8:16-17, and 1 Peter 1:7 to stress the rewards of suffering for Christ.

There are also marked similarities between Lock's 1590 poem, "The necessitie and benefite of affliction," and Dowriche's 1596 "Verses written by a Gentlewoman, upon the Jaylors Conversion," and it is possible that Lock's poem may have inspired Dowriche's. Both poems are written in ballad meter (a repetitive but memorable verse form), and both focus on the issue probably most pressing to the average reader: the cause of and appropriate response to suffering. Lock develops Taffin's argument that God allows the elect to suffer temporarily at the hands of the wicked in order to draw them to repentance and obedience, while Dowriche develops her husband's argument that the elect should respond to afflictions by repenting and renewing their faith. ${ }^{33}$ Both poems console readers by assuring them that the godly will triumph over the wicked and encourage the godly to repent by drawing on biblical phraseology: walking "astray," "scourging," "rods," God's "loving" correction. ${ }^{34}$ Lock claims that "ere we felt the scourging rod, / we er'de and went astray: / But now we keepe the law of God, / and waite thereon alway" (117-20; italics mine), and Dowriche writes, "Though God permit his chosen flocke, / Sometimes to walke astraie: / Yet sets he both the times and meanes, / To wayne them from their waie" (21-24); italics mine). Lock refers to God's "love," "rod," and "scourging rod" $(79,87,117)$, and Dowriche describes God's "eternall love," "fierie scourge," and "rod" $(12,3,9)$. Lock writes that the wicked "vexe" the righteous (16) and Dowriche notes that the jailer did "vex" the elect (30). Lock offers Job and David as models for emulation; Dowriche offers Paul and the jailer from Acts 16 .

Dowriche and Lock adopt similar rhetorical strategies in presenting their works, and Lock's dedication may have been influenced by the material prefacing The French Historie. Both women acknowledge the limitations (supposedly) imposed by their gender but draw creatively on passages from 1 Corinthians to justify their contributions to public religious debate. In addressing her brother, Dowriche humbly explains that if he is displeased by parts of the text, he must remember "that it is a womans doing. The thing it selfe will sufficientlie proove this to be

33. Ibid., chaps. 9-10; and Hugh Dowriche, Jaylor's Conversion, 22v-26v.

34. See Psalm 119:67-71, Hebrews 12:6, and Proverbs 3:12 and 13:24. 
true" (A2v). ${ }^{35}$ In the epistle "To the Reader," however, this humility vanishes as Dowriche explains that in order to fulfill the Pauline precepts concerning "edifying" and spiritual gifts (1 Cor. 12-14) her poetic "gifts" are to be used to "the glorie of God, the edifying of his Church, and the salvation of the soules of Gods chosen" (1 Cor. 14:12; A3v, A4v). Similarly, Lock humbly describes her translation as a "poore basket of stones" and claims that she is not attempting the "great things" that a woman "may not doo" by "reason of [her] sex" (77). However, Lock also alludes to Pauline precepts by stressing that her intellectual labor is part of her "calling" and that "everie one" is bound to contribute to the "furtherance" of the "holie building" and the "strengthning" of the "walles of that Jerusalem" whereof women are "Citizens and members" (77). ${ }^{36}$ Finally, Dowriche and Lock both draw on Paul's exhortations to the persecuted Thessalonians (1 Thess. 5:14): Dowriche aims to frighten the wicked but to provide "comfort to the afflicted, strength to the weake, courage to the faint hearted, and patience unto them that are persecuted" (A4r); Lock hopes to "admonish" the inexperienced, awaken the lethargic, and "comfort" the afflicted (76).

So it is clear that Dowriche and Lock contributed to local religious and literary culture; it is less clear how they were viewed by their male relatives and peers. Although there are no known tributes to Anne Dowriche by her contemporaries, Hugh Dowriche appears to have held her poetic skills in high regard. Most notably, he places her "Verses" in his volume along with his dedication to Knightley and a Latin poem by William Palfry, another friend from Oxford, and he includes Anne in this textual community of university-educated men without comment. Hugh's epistle to the reader reveals that he was a firm supporter of lay learning, and Anne's poem performs a didactic function by preparing readers for the content of the sermon and by developing her own application of Acts 16:30. As I have demonstrated elsewhere, the texts by Hugh and Anne reveal numerous instances of

35. For a detailed discussion of Dowriche's authorial self-presentation, see Susanne Woods and Margaret P. Hannay, with Elaine Beilin and Anne Shaver, "Renaissance Englishwomen and the Literary Career," in European Literary Careers: The Author from Antiquity to the Renaissance, ed. Patrick Cheney and Frederick A. de Armas (University of Toronto Press, 2002), 302-23.

36. This language recalls the note in the Geneva Bible that glosses 1 Cor. 13:8 with a reminder that spiritual gifts are necessary "for the building up of the Church." Paul refers to a Christian's "calling" in 1 Cor. 7:20 and discusses the "citizens" and "members" of the church in Eph. 2:19 and 1 Cor. 12:20ff. 
intellectual collaboration, as well as instances where Hugh appears to have borrowed from and imitated his wife's poetic skills. ${ }^{37}$

In contrast to Dowriche, Lock was praised in print by John Field and Richard Carew, but the two men responded very differently to her status as a well-connected and learned woman. In 1583 John Field printed Anne's manuscript of a sermon by John Knox and prefaced it with a dedication in which he discusses her enviable access to manuscripts by prominent preachers and the contributions that she should continue to make to the church. In flattering her in advance for her willingness to contribute additional texts to the "good of the Church," Field asserts that she is a seasoned "scholler in [God's] schoole." 38 Although Field does not explain exactly what he means by a "scholler" in "God's schoole," Calvin uses this phrase in his Commentary on the Psalms to refer to those who obtain true wisdom from God's Word and Holy Spirit. ${ }^{39}$ It is easy to see how such a phrase would be useful for an editor attempting to praise a woman who was learned but not university trained. But having described Lock as a "scholler" in God's School, Field does not stress her intellectual accomplishments or religious writing, a curious omission in a dedication that stresses the importance of promoting godly texts. ${ }^{40}$ Indeed, in contrast to Lock's later assertion that it was her duty to contribute to the church by translating and writing poetry, Field praises her only for enduring exile and exhorts her to forward more manuscripts to him.

A very different attitude is shown in a previously unknown description of Anne Lock in Richard Carew's The Survey of Cornwall (1602). By 1589, Anne Lock's daughter, also Anne, had married Robert Moyle, a gentleman from Bake, and Richard Carew, a kinsman and neighbor

37. Micheline White, "Power Couples and Women Writers in Elizabethan England: The Public Voices of Dorcas and Richard Martin and Anne and Hugh Dowriche," in Framing the Family: Representation and Narrative in the Mediaeval and Early Modern Periods, ed. Diane Wolfthal and Rosalynn Voaden (Tempe, AZ: Medieval and Renaissance Texts and Studies, 2005), 119-38.

38. John Knox, A Notable and Comfortable Exposition upon the Fourth of Matthew (1583), in his Works, ed. David Laing (1854-56; reprint, New York: AMS Press, 1966), 4:92.

39. For example, Calvin refers to those who are scholars, learned, or proficient in God's "school" in his commentaries on Ps. 25:14; Ps. 73:16-17; Ps. 119:130, 171. See The Psalms of David and Others. With Mr. Calvins Commentaries, trans. Arthur Golding (London, 1571). John Gee will use the phrase "proficient in God's school" to describe the devotional expertise of Ursula Fulford (see below).

40. Field would have been aware of Lock's translation of Calvin's sermons and of her 1572 manuscript poem, and James Sandford's Houres of Recreation (1576) demonstrates that she was known in London for her learning. See Felch, "Noble Gentlewomen." 
of the Moyles, chooses to describe the manor of Bake by associating it with the learned, but now deceased, Anne (Vaughan) Lock. At the beginning of The Survey, Carew states that the "Eulogies" in his work are based on "the sinceritie of a witnesse" and the "affection of a friend," a claim that strongly suggests that Carew had met Lock in person, and, in contrast to Field, Carew explicitly praises Lock's "rare learning." ${ }^{41}$ He writes: "In this parish lyeth Bake, the mansion of the foreremembred M. Ro[bert] Moyle, who maried Anne daughter of M. Lock, as he [M. Lock] did mistris Vaughan, a Gentlewoman suppressing her rare learning, with a rarer modesty, \& yet expressing the same in her vertuous life and Christian decease" (Survey, 109v-110r). Carew was himself a poet and linguist, and with a rhetorical finesse that recalls Lock's self-representation, he simultaneously praises her accomplishments while stressing her female modesty; he states that she "suppress[ed] her rare learning, with a rarer modesty," yet he confirms that she "express[ed]" that learning in "her vertuous life and Christian decease." The claim that Lock displayed learning in her "decease" suggests that she performed the type of intellectually demanding deathbed drama so valued by the godly, while the lack of specificity in Carew's assertion that Lock "expressed" her learning in her "vertuous life" preserves her modesty while enabling those who knew her to fill in the details (is he referring to her translations or poems; the education of her children; public displays of learned piety?). ${ }^{42}$

\section{THE DOWRICHES, THE PROWSES, AND THE ROUSES}

Along with their literary contributions to the Puritan religious agenda, the Dowriches, the Prowses, and another local couple, the Rouses, used their wealth, status, and power to strengthen the "walls of Jerusalem," both in their counties and abroad. For example, in 1582-83 the city of Geneva appealed to the English for help in withstanding the duke of Savoy. The English authorities described the siege of Geneva as a persecution launched by the pope against a "nursery" of "God's church," and they exhorted the "wealthier sort of the clergy, and other

41. Carew, Survey, 4. As noted above, Carew was related to the Locks of London through his wife.

42. Ralph Houlbrooke discusses the Puritan emphasis on a dying individual's dramatic demonstration of knowledge and faith in "The Puritan Death-Bed, c. 1560-c.1660," in The Culture of English Puritanism, 1560-1700, ed. Christopher Durston and Jacqueline Eales (New York: St. Martin's Press, 1996), 122-44. 
godly affected" laity to recall the generosity that Geneva offered to English exiles during the Marian persecution. ${ }^{43}$ The list of contributors from Exeter reveals that Richard Prowse was one of the most generous donors; his donation was surely undertaken in collaboration with his wife, a former refugee in Geneva. ${ }^{44}$ There was also a separate donation of twenty shillings made by a "M[ist]r[es]s Anne Locke," and although it is possible that this was made by Anne Lock Prowse, it is more likely that it was made by her daughter. Hugh Dowriche also made a contribution to this collection, and in The French Historie, Anne stresses that God confounded the Constable of France when he boasted in 1557 that he would quash "Geneva to the ground" (6v). ${ }^{45}$ In 1584, Richard Prowse was one of the first citizens to sign Exeter's copy of the Bond of Association and to vow to use his power, body, lands, and goods to defend England against Catholic enemies and to overthrow any who should try to harm the queen. ${ }^{46}$ As a woman, Anne Dowriche did not have the power of a citizen or property holder, but she draws on the power of poetry to achieve a similar goal; she exhorts readers to beware of treacherous "Papists" (A3v), to prepare to defend the truth to the death $(8 \mathrm{r})$, and to root out the "Popish hearts of fained frends" $(37 \mathrm{v})$.

The Dowriches and the Prowses also had connections to some of the same beleaguered Puritan ministers. Hugh's "first friend," Valentine Knightley, helped Edmund Snape when he was imprisoned in 1590; Richard Prowse and the countess of Warwick (and probably Anne Lock) assisted Snape in the years that followed. It is unclear whether Anne Lock was still alive in 1600 , but it seems likely that she would have been involved (at least until her death) in the lengthy process that led to Snape's appointment as Exeter's city preacher after a tenyear suspension for nonconformity. Ian Gowers explains that the push for a city preacher began in Exeter in 1587, and he notes that although Snape's appointment in 1600 was controversial, it was supported by the countess of Warwick, who wrote a letter on Snape's behalf, and by citizens like Richard Prowse, who contributed to Snape's stipend. ${ }^{47}$

43. The Remains of Edmund Grindal, ed. William Nicholson (Cambridge University Press, 1893), 434-35.

44. Devon Record Office (DRO), Chanter 41, fol. 325. A total of 130 people from Exeter made donations ranging from three pounds (sixty shillings) to two shillings. Two men contributed three pounds, while three men, including Prowse, contributed two pounds (forty shillings).

45. Hugh Dowriche, who was the rector of Lapford at the time, gave five shillings, an average contribution. DRO, Chanter 41, fol. 318.

46. Beatrix F. Cresswell, "The Exeter Bond of Association, with Some Notes on the Signatures," Transactions of the Devonshire Association 44 (1912): 266-77.

47. Gowers, Puritanism, 138-41, 224; Collinson, Elizabethan, 442. 
Three years later Snape was removed from his post because of his theological views, but he continued to preach privately in Devon, and in 1604 he was in London discussing legal strategies with Melanchthon Jewell and Anne Dowriche's relation Sir Edmund Prideaux. ${ }^{48}$

Another neighboring family, the Rouses of Halton (north of Mount Edgcumbe) were also committed to the "building" of the persecuted church. Sir Anthony Rous of Halton (died 1621), his first wife, Elizabeth (died before 1589), and his second wife, Philippe (died 1620), were close friends with the Carews and the Moyles, and they harbored ministers from Scotland, Ireland, and the Netherlands. ${ }^{49}$ Although it is unclear who the ministers from the Netherlands or Ireland were, we know that the Rouses employed the Scottish Presbyterian minister John Cowper as their chaplain between 1583 and 1585. Some of Cowper's colleagues went to London, where they were in close contact with Anne Lock's friend John Field. ${ }^{50}$ Cowper returned to Scotland with a letter signed by Elizabeth and Anthony Rous in which they testified that for the "zeal we had to the furtherance of the Kingdom of Christ and edification of us and our family ... we did agree with . . . Mr. John Cowper ... (being banished from his native country for the testimony of the Lord Jesus Christ) to abide and remain with us in our family to ... instruct us in the points of our salvation" and to open up "to us the word of God thrise a week." 51 Anthony Rous attended a religious "exercise" at Saltash along with other local gentlemen, and he too supported Puritan preachers found on Jewell's list. ${ }^{52}$ Halton was also a household that placed a premium on devotional reading and writing. Charles FitzGeffrey claimed that Anthony "hardly left any godly Booke out of his hands" and "drew up a booke of such notes and passages in the Bible, as he had found ... to be comfortable" for his children; Elizabeth and Anthony's son, Francis, wrote religious works; and Philippe apparently devoted two hours a day to private

48. Gowers, Puritanism, 142-43, 287.

49. Charles FitzGeffrey, Elisha his Lamentation, for his Losse. A Sermon Preached at the Funeralls of Sir A. Rous (London, 1622), 40-41. The presence of a Protestant minister from the Low Countries at Halton before 1590 might help explain Anne Lock's decision to translate Jean Taffin's Of the Markes of the Children of God.

50. Collinson, Elizabethan, 233, 276-77.

51. Sir Victor Warrender, Papers, ed. Annie I. Cameron (Edinburgh: T. \& A. Constable, 1931), 1:171, 205-6.

52. Ibid., 1:203-4. Carew describes the divisive nature of the exercise in Survey, 112v. Rous supported Samuel Hieron and gave Henry Wallis the living of St. Dominick's in 1586; both men were on Jewell's list of "resolute Puritans." Gowers, Puritanism, 87, 8285. Samuel Hieron, All the Sermons of Samuel Hieron (London, 1614), 96. 
prayer. ${ }^{53}$ In addition, the Elizabeth Rous who signed Cowper's letter in 1585 might have been the woman involved in a reprinting of Katherine Parr's Prayers or Meditations. There is no known copy of this text, but we do know that in 1587 Parr's Prayers or Meditations (1545) was "newly Imprinted at the request of mistres Elizabeth Rous, and is intytuled The sweete songe of a synner." ${ }^{44}$ This retitling of the Prayers is intriguing because it reframes the text as a companion to Parr's The Lamentation of a Sinner, a work also sponsored by a woman (the duchess of Suffolk).

\section{ANNE MOYLE AND ROBERT MOYLE}

While it has long been known that Anne Lock's son, Henry Lock, wrote poetry, newly uncovered evidence reveals that her daughter Anne (1561-1604), who married Robert Moyle, a gentleman from Bake, was a learned woman active in nonconformist circles. ${ }^{55}$ It is not clear when Lock's daughter arrived in the West Country, but, as we have seen, a "m[ist]r[es]s Anne Locke" donated twenty shillings to the Exeter fund for Geneva in 1583, and by 1589 Anne and Robert Moyle had a son, John. ${ }^{56}$ Both Robert and Anne Moyle were active members of the local literary community: Richard Carew thanks his "learned and religious kinseman Master Robert Moyle" for contributing to The

53. FitzGeffrey, Elisha, 41-43; FitzGeffrey, Deaths Sermon Unto the Living Delivered at the Funerals of the Religious Ladie Philippe, late Wife unto . . Sr Anthonie Rous (London, 1620), 28-29.

54. A Transcript of the Registers of the Company of Stationers of London, 1554-1640, ed. Edward Arber (1875-94; reprint, New York: Peter Smith, 1950), 2:474. Although there is no way to prove definitively that the woman involved in this reprinting was Elizabeth Rous of Halton, "mistress" refers to a person of elevated social standing. Rous is a Cornish name, and the Elizabeth Rous from Halton was interested in religion.

55. Robert Moyle's will confirms that his wife was the daughter of Henry Lock and Anne Vaughan: it refers to his "wife's uncle Stephen Vaughan" and to his wife's brother, Michael Lock. PRO Ward 7/37/147. Anne Vaughan Lock had a brother, Stephen Vaughan, and her surviving children, Henry, Anne, and Michael, were baptized in 1560, 1561, and 1562. Registers of St. Mary-le-Bowe, Cheapside, ed. W. Bruce Bannerman (London: Harleian Society, 1914-15), 6-7.

56. DRO, Chanter 41, fol. 325. A monument erected by John Moyle's wife stated that he died in 1661 at age seventy-two. B. H. Williams, Ancient Westcountry Families and Their Armorial Bearings (Penzance: J. A. D. Bridger, 1916), 153. Anne Lock Prowse may very well have visited her daughter at Bake to assist with John's birth or the births of other Moyle children. She might then have had the opportunity to meet the Carews and perhaps also the Rouses or the Edgcumbes. The St. Germans Parish Register shows that Anne Moyle was buried on April 12, 1604, and that Robert was buried on May 9, 1604. Robert's will, written on May 8, 1604, names six surviving children. 
Survey of Cornwall, and Anne and Robert Moyle were praised for their piety and literary skills in Charles FitzGeffrey's Affaniae. ${ }^{57}$ The third book of this collection of Latin poems by the Cornish poet-preacher FitzGeffrey includes a group of poems addressed to his future patron, Anthony Rous of Halton, and to his neighbors and friends Richard Carew and Robert and Anne Moyle. FitzGeffrey praises all four for their learning, and the poems reveal that writing of various sorts circulated among them. ${ }^{58}$ Although it is possible that works by Anne and Robert were printed, it seems more likely that they circulated in manuscript. Like John Field, Hugh Dowriche, and Richard Carew, FitzGeffrey faced the challenge of representing a learned woman in print, and, with surprising boldness, he describes Anne as a "learned" woman with a "manly heart" and stresses her facility with "Greek wit" and "Latin song." However, while FitzGeffrey claims that Rous's and Carew's learning contributes to the health of the nation, he leaves Anne within a feminized mythological realm of Muses, goddesses, and breast-feeding.

The poem is addressed "To Anne Moyle, Robert's Spouse, Most Learned and Most Pious," and continues:

Bearing a manly heart in a woman's bosom

Whose breast Urania washed thrice in Greek wit

To whom the goddess Thalia bestowed Latin song:

$\mathrm{O}$ which goddess of wisdom shall I say once led you

Into (her) innermost shrine or nourished (you) with her breasts?

I believe in fact it was Pandora: but rather I think she

Was nourished from your breasts.

Or just as Pandora alone was begot by a thousand deities

So you alone were begotten by a thousand Pandoras. ${ }^{59}$

The first line of the poem is missing, but the second line describes her as one "bearing a manly heart in a woman's bosom." The nature of

57. Carew, Survey, 38v. Charles FitzGeffrey, Caroli Fitzgeofridi Affaniae: Sive Epigrammatum Libri Tres (Oxford, 1601), 123-24. Henry Lock included a sonnet to Anne and Robert Moyle in his Ecclesiastes (1597), but it makes no mention of their literary skills.

58. FitzGeffrey attended Oxford with Anthony Rous's sons, and Rous offered him the living of St. Dominick (next to Halton) in 1603. The poem to Rous praises his knowledge of the law; the poem to Carew praises his linguistic virtuosity and his devotion to books; and the poem to Robert Moyle implies that he wrote religious poetry.

59. FitzGeffrey, Affaniae, 123-24. The Latin original reads: "Ad Annam Moyliam Roberti Conjugem, Doctissimam Pietissimam. / . . . ./Faemineo gestans mascula corda sinu / Cui Graio Uranie ter pectora lavit aceto, / Cui Latium indulsit dia Thalia melos: / O quam te sophies olim in penetralia divam / Duxisse, aut mammis dicam aluisse suis? / Credo equidem Pandora fuit: quin verius illam / A mammis alitam credo fuisse tuis. / Aut divis Pandora velut sata millibus una est, / Sic tu Pandoris millibus una sata es." Translation by Shane Hawkins. 
this "manly heart" is explained as he describes her mastery of Greek and Latin, languages usually studied by men. The description of Anne receiving the gift of "Latin song" from Thalia (the Muse of comedy and pastoral) and being bathed in "Greek wit" by Urania (the Muse of astronomy and religious poetry) strongly suggests that she composed verse in classical languages or translated classical literary works into English. FitzGeffrey invokes the female Muses to describe Anne's possession of skills normally acquired by men at university, and he diffuses any sense that she has intruded into a male domain by describing her entry into a goddess's "innermost shrine" where she received knowledge through the female art of breast-feeding. Finally, he praises her manifold gifts by claiming that while Pandora (all-gifts) was created through the gifts of a "thousand deities," Moyle was begotten by a thousand Pandoras. ${ }^{60}$ FitzGeffrey's depiction of Anne's classical learning suggests that her learning (like her mother's) was valued in this Cornish literary community.

FitzGeffrey provides no indication of the political orientation of the works produced by Anne or Robert Moyle, but extraliterary evidence indicates that the Moyles, like the Prowses, the Dowriches, and the Rouses, contributed to the "godly" agenda. In 1596, Robert Moyle and a friend obtained the lease for the parsonage and rectory of St. Germans in hopes of providing for a preacher, and Moyle left money in his will to ensure that the church retained its preacher, the nonconformist William Doddinge: "for the zealous care I bare to the house of God, and for the continuance of the preaching of the Word . . I freely give and allow, unto William Doddinge, meat, drink, diet, and lodging, in my house of Bake . . . as long as he shall exercise the ministry and as the Lord's watchman, continue to be preacher." 61 William Doddinge, who is referred to elsewhere in Moyle's will as a "godly" friend, was found on Jewell's list of "resolute Puritans" and subsequently suspended for refusing to conform. ${ }^{62}$ Moyle also appointed

60. Although Pandora set loose the evils sent by Zeus to punish man, poets often ignored this part of the myth, focusing instead on Pandora as a woman who embodied all virtues. In his Teares of the Muses (1591), Spenser refers to Queen Elizabeth as a "most peereles Poetresse, / The true Pandora of all heavenly graces" (577-78).

61. A Catalogue of the Ancient Deeds and Papers in the Muniment Room at Port Eliot, St. Germans, Cornwall, arranged and compiled by Charles Henderson, 1925-27, n.p. Available at the Royal Institution of Cornwall, Truro. Robert Moyle's will was written on May 8, 1604. PRO Ward 7/37/147. It is possible that the Moyles also supported a previous Puritan incumbent, "Mr. Tuke," who was named along with John Field, Walter Travers, and Melanchthon Jewel in a 1586 petition for suspended preachers. Peel, Seconde, 2:262.

62. Gowers, Puritanism, 77-78. 
his "godly friends," the preachers "Mr. Walter Travers [and] Mr. Stephen Medhoppe" to assist the executors of his will. This Walter Travers is almost certainly the famous London preacher whose suspension outraged Puritans throughout the period; Stephen Medhoppe, a Cornish minister on Jewell's list, was in London in 1604 conferring with Jewell, Snape, and Sir Edmund Prideaux, who was also a kinsman of the Moyles. ${ }^{63}$ In addition, Anne Moyle was the godmother of an Anne Travers, almost certainly the daughter of John Travers and the girl who was baptized at St. Germans in April 1599. ${ }^{64}$ John Travers, also included in Jewell's list, was the brother of Walter Travers; he was jailed for organizing unauthorized public fasts, for adhering to "particular opinions," and for insulting the Bishop of Exeter. ${ }^{65}$ The Moyles' friendships with all these radical ministers might explain why an assize judge complained in 1587 that Robert Moyle was the "furious maintainer of factions in that country" and recommended reviewing his position as a justice of the peace. ${ }^{66}$ Thus, although FitzGeffrey depicts Anne Moyle exercising her learning and piety in a quiet, mythological realm, the evidence suggests that she would have been an eager reader of the politically charged works by her mother and Anne Dowriche, and that she too may have used her gifts to further the "godly" agenda.

\section{URSULA FULFORD AND THOMAS FULFORD}

In 1580, Ursula Bampfield Fulford (ca. 1566-1639), who was distantly related to the Dowriches and the Edgcumbes, married Thomas Fulford (died 1610) from Fulford House, a seat eight miles west of Exeter, and although Ursula and Thomas did not support radical Puritans, they shared many of the religious goals of the other local families: they encouraged the dissemination of printed Protestant texts; they supported preachers; they circulated religious poetry; and they were vehemently

63. Gowers, Puritanism, 73, 287. Peel, Seconde, 2:108. Like Anne Dowriche, the Moyles were related to the Prideaux family. Robert Moyle's sister, Anne, was married to John Prideaux, probably the nephew of Sir Edmund Prideaux, and was buried at St. Germans in 1596. In 1612, Anne and Robert Moyle's son, John, married Admonition, the daughter of Sir Edmund Prideaux. St. Germans Parish Register. See also J. L. Vivian, ed., The Visitations of the County of Cornwall, Comprising the Herald's Visitation of 1530, 1573, and 1620 with Additions (Exeter, 1887), 334; and Vivian, Devon, 621.

64. PRO, Ward 7/37/147. St. Germans Parish Register.

65. John Travers was the rector of Farington, Devon, in the 1580s and 1590s, but he was admitted to Landrake (across the river from Bake) between 1599 and 1600 . Gowers, Puritanism, 69-70, 287. Inner Temple Library, Petyt MS 538/38, fol. 62.

66. Lansdowne MS 53, fol. 170v. Moyle was also accused of being "envious, proud, corrupt, [and] inconsiderate." He maintained his position. 
anti-Catholic. ${ }^{67}$ Although previously unknown to feminist historians and literary scholars, Ursula Fulford was the recipient of printed dedications that praise her for advancing Protestantism in the West Country, and she also appears to have been a poet. As we shall see, poems by John Chardon strongly suggest that she wrote religious poetry, and she may have composed the pious verses on her husband found on a family funeral monument.

In 1594, John Chardon preached a sermon at the cathedral in Exeter in commemoration of the defeat of the prayer book rebellion of 1549; it was printed in 1595 at the request of the Fulfords. ${ }^{68}$ The title of the text, Fulford et Fulfordae: A Sermon Preached at Exeter . . in Memorial of the Cities Deliverance in the Daies of King Edward the Sixt, draws attention to Exeter's troubled past and to Ursula and Thomas's joint effort to further the progress of Protestantism. In the dedication, Chardon describes Ursula as a "zealous Gentle-woman," and he depicts the Fulfords as champions of the "holy Gospell," of the ministers of the Gospel, and of the printing press. He explains further that while he thought they would be content with a private copy of his sermon, they desired "to make common unto many which was then uttered unto fewe." 69 His volume includes Latin poems dedicated to Ursula and Thomas, but the poems to Thomas are remarkably impersonal; there is a poem summarizing the sermon (on Isa. 1:2-3) and a longer poem that

67. Vivian, Devon, 287, 378-80. Vivian, Cornwall, 142. One of these connections suggests that Ursula would have had a personal interest in The French Historie. Both Ursula's daughter and Anne Dowriche's sister married members of the Champernown family, a family of soldiers who fought for the Huguenots, married into a prominent Huguenot family, and participated in the events recounted in The French Historie. On October 10, 1580, a marriage license was issued to "Mr. Thomas Fulford, Esquire, and Ursula Bampfield, Gent." J. L. Vivian, ed., The Marriage Licenses of the Diocese of Exeter from the Bishop's Registers (Exeter, 1887), 6. Thomas Fulford was removed from his position as JP in 1587 for being "verye furious \& inconsyderate." Lansdowne MS 53, fol. 170r. It is not clear what Fulford did to earn such a reputation.

68. It is certain that Richard Prowse (and Anne, if she was still alive) would have attended this sermon. It was an annual event in Exeter and was attended by the mayor and aldermen in state. Chardon may also have known the Dowriches because in 1584 he preached in Exeter at the funeral of his patron, Sir Gawain Carew, who was a relation of the Dowriches. Chardon also dedicated two texts to the earl of Warwick, the man who assisted Valentine Knightley and whose wife was the dedicatee of Anne Prowse's 1590 translation.

69. John Chardon, Fulford et Fulfordae: A Sermon Preached at Exeter (London, 1595), A2r-v. In addition to promoting Chardon's printed sermon, Ursula shared the advowson for a rectory in Somerset with her husband, and she probably used this position to promote Protestantism as well (Somerset Incumbents, from the Hugo MSS 30 279-30 in the British Museum, ed. Frederic William Weaver [Bristol, 1889], 320). The advowson was for the rectory at Brompton Ralph in the Archdeaconery of Taunton. 
offers maxims on spiritual life. By contrast, the three Latin poems for Ursula are intensely personal and suggest that she wrote devotional and elegiac verse. For example, in the second Latin poem (translated here), Chardon contrasts Ursula with Sappho:

Lesbian Sappho used to sing wanton poems, Heavenly Ursula [sings] the renowned victories of God.

The Lesbian friend gave Phoebus a lyre: Ursula will bear to Phoebus Prayers enclosed in her own faithful heart.

Ursula, should your only desire be to serve God,

[then] You would regard true joys: glory will be [your] end. ${ }^{70}$

Chardon is drawing here on Ovid's Heroides, a text in which Sappho is artistically incapacitated by (heterosexual) desire and commits suicide after dedicating her lyre to Phoebus. For Chardon, Sappho serves both as a model of female poetic excellence and as a moral foil against which to celebrate Ursula's devotional productions. Just as Anne Dowriche offered The French Historie as a corrective to "wanton vanities" (A4r), so Chardon contrasts the "wanton poems" sung by Sappho with Ursula's godly utterances. Ursula sings "heavenly" poems; she offers "prayers" to Phoebus; and she recognizes that "true" joys come from spiritual, rather than erotic, desire.

The first and third poems have a different focus and suggest that Ursula may also have composed elegiac verse or songs. The first contains the sentiments:

Ursula, in mourning I would have wept for the songs you uttered,

If I had thought that you had studied the scriptures too little,

But the holy page of the Messiah defends

Your heart against the preludes of the false world. ${ }^{71}$

The subject matter of these sad "songs" is clarified somewhat by the third poem, which speaks directly of English flowers perishing from disease:

Ursula, do you know how gathered flowers begin to wilt, And flourishing roses die in spring-time?

Do you see the English lilies begin to droop from disease, Lilies which had been worthy in your eyes?

70. The second poem reads: "Lesbia cantabat lasciva poemata Sappho, / Ursula coelestis clara trophea Dei. / Lesbis amica chelyn Phoebo dedit: Ursula Phoebo, / Vota feret fido pectore clausa suo. / Ursula, Sola Deo tua sit servire voluptas, / Gaudia vera putes: gloria finis erit." All the translations of Chardon's poems are by Shane Hawkins.

71. The first poem reads: "Ad Ursulam Thomae Fulfordi conjugem Orthodoxam. / Ursula, funesto flerem tua carmina sata, / Biblia si scirem te coluisse parum. / Ast munit contra falsi praeludia mundi, / Messiae pectus pagina sancta tuum." 
In this you can catch a whiff of the glory of this world, Which quietly dissolves into fine ashes. ${ }^{72}$

Between 1592 and 1594, the plague reached epidemic proportions in England, and Chardon's references to sad "songs" and "lilies" drooping from "disease" seem to suggest that Ursula Fulford wrote elegies for lost family members. ${ }^{73}$ These poems complement Chardon's prefatory claim that Ursula supported the promulgation of the "Holy Gospell" by stressing that she has been prepared to deal with personal grief by "stud[ying]" the "holy page of the Messiah." The fact that Chardon, who clearly benefited from Ursula's support, chooses to depict himself in print as a discerning reader of her "songs" and "prayers" suggests that these "songs" were important to Ursula's religious identity. We are reminded of FitzGeffrey's praise of Anne Moyle's piety and literary abilities.

Ursula Fulford was also publicly thanked for her support in a 1625 dedication by John Gee, her godson and the minister of St. Mary's Church in Dunsford. Gee claims to be "deepely bounden" to both Ursula and another gentlewoman from Devon, and he offers them a collection of prayers entitled The Steps of Ascension unto God, or A Ladder to Heaven. ${ }^{74}$ Claiming that the women are widely known for the "ornaments" of their minds and their "Integrity, Piety, [and] Zeale," Gee draws on their status to promote his own work (A2v). Like Field, Gee draws on the notion of "God's school," but, in contrast to Field, he stresses the women's devotional expertise, and he simultaneously offers them his prayers and asserts that they have no need for them: "[You do not] neede my weake instruction, for you are both known to be good Proficients in Gods schoole, and have more of this heavenly language in you by heart, then I can teach you by precept" (A2v). Having established that he is not presuming to "instruct" the women, Gee urges them to use their authority to promote his work among

72. The third poem, "Ad Eandem," reads: "Ursula, collectos cernis flaccescere flores, / Et verno nitidas deperisse rosas? / Anglorum spectas marcescere lilia peste, / Quae fuerant oculis lilia digna tuis? / Hinc subolere potes quaenam sit Gloria mundi, / Quae tacite tenues soluitur in cineres."

73. The Dunsford Parish records do not contain burial entries for any children born to Ursula before 1595 , but there may have been children buried elsewhere. Chardon also refers to the cruelty of death, the death of flowers, and the transience of all things in his poem to Thomas. Ursula's "songs" might also have been related to the death of her father (May 1594) or of her brother who had died on the way to Ireland.

74. J[ohn] G[ee], The Steps of Ascension unto God, or A Ladder to Heaven. Contayning Prayers and Meditations for every day of the weeke, and for all other times and occasions (London, 1625), A2r. Further page references to this volume appear parenthetically in the text. For a brief biography of Gee, see the Dictionary of National Biography. 
the unlearned: "You might have (I doubt not) a better Card or Compasse to saile by then this forme of prayers which I prescribe, yet I beseech you incourage others (that are weake) to feed upon this milke for babes, by tasting of it yourselfe" (A4r). The dedication also enlists the women in the effort to combat residual Catholicism, for Gee stresses that he is not "thrusting" into their hands a "Popish Manuell, Coronary, or Rosary ... (all which I know are but weake reedes and rotten staves to leane upon) but I send you with petition unto him who is the fountaine of mercies, and God of all comforts" (A3v).

These textual representations of Ursula's and Thomas's piety correspond with the Fulfords' sense of their identity as displayed in the large joint monument in St. Mary's Church in Dunsford (see fig. 3). The monument features large recumbent effigies of Thomas and Ursula beneath smaller effigies of their seven children, who kneel before an open Bible. A sixteen-line verse inscription (now lost) stated that the monument commemorated "Thomas Fulford, Miles, who died the last day of July, Anno. Do. 1610," and it specifically praised his "true Pietye," his adherence to Protestant doctrine, and his hatred of "Popish Crewe." 75 It also stated that he loved "his Mate in all his life, For being [a] true and virtuous wife." It is not known when the monument was designed or erected, but the fact that it gives a precise date for the death of Thomas but not for Ursula suggests that it was erected before her death (1639), and that she may have composed the verse inscription. ${ }^{76}$

\section{VII . C ON CLUS I ON}

In concluding this study at this juncture, I do not mean to suggest that the recovery of women writers in the West Country is complete: there are other learned women who were engaged in literary activities

75. Richard Polwhele, The History of Devonshire (1793-1806; reprint, Dorking: Kohler \& Coombers, 1977), 2:80. The inscription said: "This monument doth represent, / Him that was worthy by discent, / O grant, Lord! his may live and dye, / Myrrors of like true Pietye, / And when their days shall ende as his, / Send them that glory, where he is. / Faithful to King he was, and true / Unto all kind but Popish Crewe. / Lovinge his Mate in all his life. / For being true and virtuous wife. / On Christ alone his ancre cast, / Requiring helpe of him at last. / Death was the doore through which he went, / Into that happiest Firmament. / Then if we think to gain hereby, / O lett us learn to live and dye." This verse inscription was replaced when the monument was restored in 1845 .

76. Nigel Llewellyn notes that a large proportion of monuments were commissioned, carved, and seen by their subjects before their deaths. Nigel Llewellyn, Funeral Monuments in Post-Reformation England (Cambridge University Press, 2000), 53. 


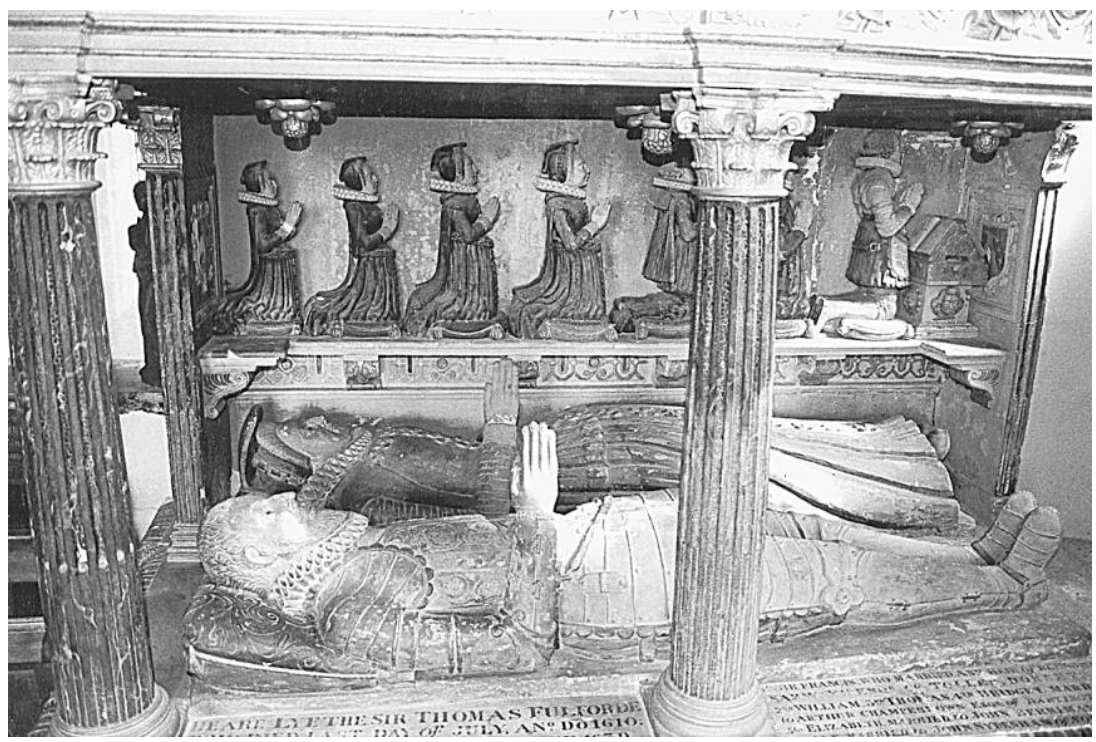

Figure 3. The monument to Sir Thomas and Ursula Fulford in St. Mary's Church, Dunsford, Devon.

and who had ties to these women or to the same network of Puritan preachers. ${ }^{77}$ Discussions of circles and networks are inevitably incomplete, for in focusing on selected relationships within a dense web of associations, one inevitably passes over other relationships. Lock, Dowriche, Moyle, Rous, and Fulford may indeed have had connections to other local learned women, but, as we have seen, these five learned and pious women can fruitfully be discussed in terms of their familial, geographical, and ideological ties. And, while this information cannot claim to be comprehensive, it does enrich our understanding of the Renaissance woman writer on several fronts. First, the discovery of evidence pertaining to the literary and religious activities of previously unknown women such as Anne Moyle, Ursula Fulford, and perhaps Elizabeth Rous reminds us that lists of extant printed works represent only part of women's literary activities, and that women's religious writings should be interpreted alongside nonliterary forms of religious activism. Second, quite contrary to Woolf's description of the isolated Elizabethan poetess, we find that these

77. For example, Lady Anne Harris Southwell of Cornworthy, Devon (1573-1636), Lady Elizabeth Courtenay (ca. 1518-1605) of Ugbrooke, Devon, and Joanne Courtenay Tremayne of Ugbrooke (died 1595). 
women were recognized as active members of vibrant religious and literary communities and were connected to each other, to specific religious and literary goals, and to the same patrons and preachers. Finally, this essay raises questions about scholarly methodology: although discussions of women's participation in literary culture will no doubt continue to be organized largely in terms of individual authors and genres, this essay demonstrates that an approach that prioritizes geographical locality, kinship, and religious affiliation provides valuable insight into connections between women and into the historical matrices in which they read, thought, and wrote. 